\title{
Review
}

\section{Life and death decisions: regulation of apoptosis by proteolysis of signaling molecules}

\author{
PJ Utz ${ }^{*, 1}$ and P Anderson ${ }^{2}$ \\ ${ }^{1}$ Stanford University School of Medicine, Department of Medicine, Division of \\ Immunology and Rheumatology, Stanford, CA 94305, USA \\ 2 Brigham \& Women's Hospital, Department of Medicine, Division of \\ Rheumatology, Immunology, and Allergy, Boston, MA 02115, USA \\ * Corresponding author: PJ Utz, MD, Stanford University School of Medicine, \\ CCSR Building, Room 2215, Mail Code 5166, 259 Campus Drive, Stanford, CA \\ 94305, USA Tel: (650) 724-5421; Fax: (650) 723-7509; \\ E-mail: pjutz@stanford.edu.
}

Received 13.12.99; revised 17.3.00; accepted 20.3.00

Edited by M Piacentini

\begin{abstract}
Caspases are the major executioners of cell death, serving as molecular guillotines to behead many proteins required for maintenance of cellular homeostasis. Identification of caspase substrates has taken on increasing importance as we attempt to better understand the molecular mechanisms involved in regulating the struggle between life and death. Many caspase substrates have been described and include RNA binding proteins such as La and U1-70 kD, structural proteins such as keratin and nuclear lamins, and transcription factors or their regulatory proteins that include $I_{\kappa} B, S P 1$, and SREBP. Kinases and other signaling proteins are perfectly suited to regulate life and death decisions in response to cellular stressors and have only recently been identified as important caspase substrates. Here we review the current status of signaling pathways that are activated, inactivated or dysregulated by proteases such as caspases and calpain to control entry into apoptosis. The emerging concept that some caspase pathways may be inhibited by cellular and viral apoptosis inhibitory proteins while other caspase pathways are preserved suggests that a subset of these kinases may exist as cleaved 'isoforms' in cells that are not destined to perish. By acting as executioners and as important 'molecular sensors' of the degree of cellular injury, the signaling proteins described in this review are strong candidates to mediate downstream events, both in condemned and in viable cells. Cell Death and Differentiation (2000) 7, 589-602.
\end{abstract}

Keywords: apoptosis; signaling; kinase; caspase

Abbreviations: APC, antigen presenting cell; ASK-1, apoptosis signal-regulating kinase-1; CaMK, calcium/calmodulin-dependent protein kinase; CDK, cell cycle dependent kinase; CDKI, cdk inhibitor; DNA-PKcs, DNA-dependent kinase catalytic subunit; FADD, Fas-associated death domain protein; FAK, focal adhesion kinase; FAP, Fas-associated phosphatase-1; FAT domain, focal adhesion targeting domain; FLICE, Fas-associated death-domainlike IL-1beta-converting enzyme; FLIP, FLICE-inhibitory protein; GTPase, guanine triphosphatase; HUVEC, human umbilical vein endothelial cells; IAP, inhibitor of apoptosis; $1 \kappa \mathrm{B}, \mathrm{NF}-\kappa \mathrm{B}$ inhibitory subunit; ITAM, immunoreceptor tyrosine-based activation motifs; JNK, jun N terminal kinase; LOK, lymphocyte-oriented kinase; MAPK, mitogen-activated protein kinase; $\mathrm{MHC}$, major histocompatibility complex; NF- $\kappa \mathrm{B}$, nuclear factorkappa B;PAK2, p21-activated kinase 2; PCNA, proliferating cell nuclear antigen; PI3-K, phosphatidylinositol 3-kinase; PKC, protein kinase C; Plkk1, pololike kinase 1; PP2A, protein phosphatase 2A; RIPK, receptorinteracting protein kinase; SAPK, stress-activated protein kinase; SDS-PAGE, sodium dodecyl sulfate polyacrylamide gel electrophoresis; SH2, src homology domain 2; SRP72, 72 kD subunit of the signal recognition particle; $\mathrm{SR}$, serine/arginine splicing factor; SRPK, SR protein kinase; SLK, Ste20-related kinase; TCR, T cell receptor; TIL, tumor infiltrating lymphocytes; TNF, tumor necrosis factor; TNFR, TNF receptor; TRADD, TNF receptor-associated death domain protein; TRAIL, tumor necrosis factor-related apoptosis-inducing ligand; UV, ultraviolet; ZAP-70, $\zeta$-associated protein of $70 \mathrm{kD}$

\section{Introduction}

The activation of caspase pathways and the resultant cleavage of substrate molecules mediates a critical function in the regulation and execution of cell death. The importance of these protease pathways is underscored by two important observations. First, many modified proteins are targets of autoantibodies in diseases such as systemic lupus erythematosus (SLE), dermatomyositis (DM) and scleroderma. It has been proposed that the site-specific cleavage of substrate proteins by caspases and other proteases such as granzyme $B$ is intimately involved in the generation of an immune response to these molecules. ${ }^{1-4}$ Second, an expanding number of kinases and signaling adaptor proteins have been reported as specific substrates of caspases, suggesting that multiple aspects of cell death and cell survival may be mediated through cleavage of a variety of signaling molecules. $^{5}$

Apoptosis is a highly regulated and organized death process that serves critical functions in the deletion of autoreactive lymphocytes, elimination of virally-infected and malignant cells, and development of complex multicellular organisms. Given the tremendous daily turnover of apoptotic cells in an individual, it is not surprising that strict regulations must be enforced by the organism to insure that the proper life/death decision is made. Even minor changes in this delicate balance within a given population of cells could have profound implications on the 
well-being of the organism. For example, excessive apoptosis would generate too much apoptotic debris (e.g., leading to inflammation, which normally does not occur in response to apoptotic material) and too few cells to perform their required function (e.g., leading to cellular aplasia). Insufficient apoptosis would result in failure to delete autoreactive lymphocytes (e.g., leading to autoimmunity) or uncontrolled cellular proliferation (e.g., leading to tumor). For these reasons, the identification of key components of the cell death machinery, and the mechanisms by which these molecules determine the apoptosis threshold, have become important areas of research.

The key effectors of cell death are caspases, a family of cysteine proteases that cleave substrate proteins following aspartic acid residues. ${ }^{6}$ Caspases are components of a proteolytic cascade that culminates in the cleavage of proteins that are essential for cell survival. The simplistic view that 'upstream' caspases serve to activate 'downstream' or executioner caspases should probably be replaced by a more integrated model in which both upstream and downstream caspases cooperate to regulate entry into apoptosis. In this view, caspases can function as both regulators and effectors of the death program. Similarly, activation of selected kinases, including PAK, JNK and ASK-1 appear to function as both regulators and effectors of cell death, whereas stimulation of other kinase pathways, including ERK1 and ERK2 function to inhibit cell death (reviewed in $^{7}$ ).

In this regard, death is determined by an integration of conflicting signals. The cell must decide, in the face of noxious environmental stimuli, whether to survive and repair the damage (i.e. induce an adaptive response) or throw in the towel and die by apoptosis. The winner in this 'death struggle' can choose several methods to insure victory, including (i) amplification of the death signal, e.g., by cleavage of MEKK-1 and MSTs; (ii) relocalization of key signaling proteins such as fyn; or (iii) tripping up the competition (e.g., cleavage of repair proteins such as DNA$\mathrm{PK}$, or of cell cycle regulatory proteins). Following their proteolytic cleavage, the signaling molecules described in this review use all three methods and several novel techniques to regulate cell death pathways en route to determining cell fate. As will become evident, signaling molecules such as kinases and adaptor molecules play critical roles in this process, particularly as 'sensors' or 'decision switches' that must be thrown in order to either repair the damage or to commit suicide.

Since this topic was last reviewed in this journal, ${ }^{5}$ the number of signaling molecules that have been identified as caspase substrates has more than doubled. This strongly suggests that disruption of diverse kinase signaling pathways may be a critical event during the cellular response to stressful stimuli. In order to better understand how kinase pathways are manipulated in response to stress, we have somewhat artificially grouped the signaling molecule protease substrates into several different categories. These include (i) signaling components that effect morphologic changes associated with apoptosis; (ii) kinases that can no longer perform cellular repair functions; (iii) signaling proteins that insure the fidelity of the cell cycle; (iv) signaling molecules that are directly associated with death receptors; (v) signaling proteins that transduce stressful or growth signals; (vi) signaling proteins associated with the $T$ cell receptor; (vii) kinases implicated in mRNA splicing; and (viii) kinases with many or undefined functions.

\section{(i) Kinases that regulate cell morphology}

During apoptosis, cells progress through a series of morphologic changes that include condensation of both the nucleus and cytoplasm, membrane externalization of phosphatidylserine, and formation of membrane blebs at the cell surface. ${ }^{8}$ These morphologic changes can in part be replicated in vitro by mixing intact nuclei with either apoptotic lysates or a mixture of recombinant caspases and nonapoptotic cell lysates. Such experiments strongly suggest that caspases play an important biochemical role in determination of the changes in cell shape and structure that are associated with apoptosis. At least four kinases that are cleaved by caspases during apoptosis have been identified as candidate effector proteins with the capacity to regulate cellular morphology. Two of these kinases (PAK2 and FAK) were discussed extensively in a recent excellent review in this journal and will be touched on only briefly. ${ }^{5}$

PAK2 is a member of a family of p21-activated kinases that are regulated through interactions with the small GTPases Rac and cdc-42. PAKs exert pleiotropic effects that include regulation of MAPK pathways as well as regulation of the cytoskeletal network that appear to be independent of their kinase activity. PAK2 has recently been identified as a caspase substrate. ${ }^{9,10}$ Cleavage of PAK2 separates its $\mathrm{N}$-terminal p21-binding domain from its C-terminal kinase domain, generating a molecule that possesses a constitutively active kinase activity. Expression of dominant negative mutant PAK2 kinase in $\mathrm{CHO}$ cells transfected with Fas, ${ }^{10}$ or in Jurkat T cells, ${ }^{9}$ prevents or delays Fas-mediated cell death. Expression of dominant negative PAK2 has a pronounced effect on cellular morphology, preventing the formation of cell surface apoptotic bodies while markedly enhancing externalization of phosphatidylserine. ${ }^{9}$ Ectopic expression of the carboxyl terminal kinase domain in many different cell types activates the apoptotic program and is uniformly associated with morphologic changes characteristically found in apoptotic cells. ${ }^{10}$ Taken together, these studies demonstrate an important role for PAK2 cleavage in both the execution phase of apoptosis and in mediating many of the observed morphologic characteristics of dying cells.

FAK is a nonreceptor tyrosine kinase that localizes to sites of contact between the cell and the surrounding matrix. Fak associates with a variety of proteins including p130Cas, Shk, PI-3 kinase, and paxillin, enabling FAK to govern cell-growth and survival pathways that are initiated when integrin receptors bind to extracellular matrix proteins. ${ }^{11}$ Since Fak mediates a critical cell survival function, it is not surprising that disruption of this signaling pathway by FAK cleavage leads to cell death. Like PAK2, FAK plays an important role in determining cell shape and regulating cell motility. Cleavage of FAK precedes the 
rounding of cells and loss of cell contact with the extracellular matrix. Whether FAK cleavage is also responsible for the observed loss of FAK from focal adhesions is unknown, and a recent report provides evidence for a FAK dephosphorylation event in this phenomenon. ${ }^{12}$ Cleavage of FAK abrogates its ability to bind to paxillin but not to p130Cas. ${ }^{13}$

FAK undergoes sequential proteolysis at two sites $\left(\mathrm{DQTD}^{772}\right.$ and $\mathrm{VSWD}^{704}$ ), generating a fragment containing an intact kinase domain and another fragment containing the focal adhesion targeting (FAT) domain. ${ }^{14,15}$ That the choice of caspase cleavage sites may be of critical importance is based on several interesting observations. First, unique caspase cleavage sites are differentially recognized in individual cell lines. ${ }^{15}$ Second, ectopic expression of the C-terminal FAT (C-FAK) fragment (generated by cleavage at the DQTD ${ }^{772}$ site) promotes apoptosis, while a fragment arising from an endogenous natural variant called FRNK (corresponding to aa691, which is in close proximity to the VSWD ${ }^{704}$ cleavage site) does not induce apoptosis. ${ }^{15}$ Third, mouse fibroblasts are resistant to cell death signals, and mouse and rat FAK possess the VSWD ${ }^{704}$ cleavage site but lack the DQTD ${ }^{772}$ site (it is DQTE). Comparison of proteolytic fragments of FAK derived from apoptotic mouse or human cells by Western blot analysis confirms that mouse FAK is cleaved at only the VSWD ${ }^{704}$ site. ${ }^{15}$ Within the 68aa region that links the DQTD ${ }^{772}$ and $\mathrm{VSWD}^{704}$ cleavage sites is a proline-rich domain that has been suggested to mediate the cell-survival function of FAK. It remains to be determined whether expression of the C-terminal VSWD $^{704}$ FAK cleavage product can mediate apoptosis or apoptosis-associated cellular morphology.

RasGAP has recently been identified as another potentially important signaling molecule that regulates cellular morphology. ${ }^{16,17}$ RasGAP associates with a variety of signaling molecules including ras, and it likely coordinates competing signaling pathways. Targeted disruption of RasGAP enhances apoptosis in the central nervous system of mouse embryos. ${ }^{18}$ RasGAP is cleaved in response to a diverse array of stimuli including Fas activation, ${ }^{16,17}$ TRAIL activation, ${ }^{16}$ and exposure to chemotherapeutic agents. ${ }^{16}$ Upon cleavage of RasGAP, a ras-p21 interaction domain is separated from a neighboring $\mathrm{SH} 2$ domain, and this correlates with enhancement of rasGAP GTP hydrolytic activity in vitro. ${ }^{16}$ The precise cleavage site is inferred based on the size of the cleavage products and has not yet been definitively mapped. Interestingly, a candidate cleavage site (DTVD ${ }^{455}$ ) exists that would generate a RasGAP fragment that has been shown to mediate cell adhesion and cytoskeletal morphology. ${ }^{19}$ Thus, the precise role of RasGAP in inducing or preventing apoptosis, or in regulating cellular morphology, awaits further experimentation.

The signaling molecule that has most recently been identified as a caspase substrate is the Ste20-related kinase, SLK. Murine SLK was identified in a yeast twohybrid interaction trap as a partner for a muscle-specific transactivator protein. ${ }^{20}$ Although the two-hybrid interaction could not be validated, the binding protein was found to have extensive sequence homology with a human kinase (hSLK), with the Ste20-related lymphocyte-oriented kinase (LOK), and with the Xenopus polo-like kinase 1 (xPlkk1). Murine SLK was also homologous to human MST1 and MST2, a pair of Ste20-related kinases that are cleaved by caspases, discussed in detail later in this review. In addition to the amino terminal Ste20-family kinase domain, SLK was found to have several novel carboxyl terminal domains, including motifs found in a pair of proteins of unknown function, microtubule and nuclear associating protein (MNAP domain) and AT1-46 (ATH domain). ${ }^{21}$ This suggests that SLK is a member of a novel family of serine-threonine protein kinases.

Overexpression of SLK in several cell lines including C2C12 myoblasts, COS-1, HeLa, and NIH3T3 cells induced apoptosis, as measured by annexin $\mathrm{V}$ and TUNEL staining. Transfected cells also showed a near complete absence of stress fibers, and striking relocalization of actin to the cell cytoplasm periphery. This function was independent of SLK's kinase activity, as ectopic expression of a kinasedead mutant also led to relocalization of actin. To further characterize these two functions (apoptosis and actin disassembly), mutational analysis of SLK was performed. Transfection of amino terminal truncation mutants rapidly induced apoptosis, and this required the intact kinase domain. In contrast, expression of the carboxyl terminal SLK mutants led to actin disassembly (which required the ATH domain), followed later by cellular retraction and apoptosis.

Given the many signaling molecules that had been identified as caspase substrates, this group of investigators asked whether SLK might also be cleaved during cell death. SLK was found to be cleaved in vivo in apoptotic Rat-1 and NIH3T3 cells, but not in apoptotic MCF-7 cells, indicating that caspase 3 is required for cleavage. SLK translated in vitro is cleaved by recombinant caspase 3 , confirming the in vivo observations. Although the cleavage site was not mapped, a $62 \mathrm{kD}$ amino terminal cleavage product was consistently observed. The kinase activity of this $62 \mathrm{kD}$ product (using myelin basic protein as an artificial substrate in an in vitro kinase assay) was increased several-fold when compared to full length protein. Thus, transfection experiments using full length and mutant proteins, together with in vitro caspase cleavage and in vitro kinase assays, suggest that SLK is cleaved in response to apoptotic stressors into two fragments with separable activities - an amino terminal kinase domain that is activated upon cleavage and can itself induce apoptosis, and a carboxyl terminal fragment that is involved in actin fiber disassembly.

\section{(ii) Tripping up the competition I: prevention of cellular repair by cleavage of DNA-PKcs}

A unifying feature of many caspase substrates is that their cleavage irreversibly prevents the cell from repairing apoptosis-induced damage. Thus, many of the cleaved kinases discussed in this review might be thought of in this regard. One kinase that is clearly involved in cellular repair processes is the catalytic subunit of DNA dependent protein 
kinase (DNA-PKcs). DNA-PKcs is a $460 \mathrm{kD}$ protein that exists in a complex that also includes the $70 \mathrm{kD}$ and $80 \mathrm{kD}$ subunits of the autoantigen $\mathrm{Ku}$. DNA-PK mediates a variety of important repair functions including repair of double-stranded DNA breaks, mismatch repair, nucleotide excision repair, and cell cycle arrest through activation of proteins such as p53. ${ }^{22}$ DNA-PKcs was one of the first autoantigens described as a caspase substrate, and its cleavage has been studied extensively. ${ }^{22}$ DNA-PKcs is efficiently cleaved in vivo and in vitro in a DNA-dependent manner, and its kinase activity is diminished following cleavage, probably due to removal of an amino terminal leucine zipper motif. ${ }^{23,24}$

\section{(iii) Tripping up the competition II: kinases that regulate the cell cycle}

The activation of cyclin dependent kinases (cdks) such as cdc2 and cdk2 is associated with apoptosis. This has now been shown to occur through the caspase-mediated inactivation of an inhibitory kinase (Wee1) and two cyclindependent kinase inhibitors (CDKIs) (p27/KIP1 and p21/ CIP1/WAF1). A potential role for caspase activation of PITSLRE family kinases may also exist and will be discussed below.

Wee1 was originally identified in fission yeast through the ability of double mutants of cdc2 and wee1 to display a temperature-sensitive lethal phenotype that is associated with gross abnormalities of chromosome segregation, termed mitotic catastrophe. ${ }^{25}$ Wee1 was subsequently shown to phosphorylate and negatively regulate cdc2 in a manner that could be reversed by the phosphatase cdc25. ${ }^{26}$ Fas-induced apoptosis in Jurkat cells results in activation of cdc2 and cdk2 and loss of the inhibitory tyrosine phosphorylation at $\mathrm{Y}^{15}$ that is mediated by Wee1. ${ }^{27}$ Moreover, the diminished kinase activity of Wee1 in apoptotic cells correlates with the observed site-specific cleavage of Wee1, both in vivo and in vitro. This data fits well with several published studies demonstrating that ectopic expression of either Wee1 or dominant negative cdc2 or cdk2 mutants can inhibit apoptosis induced by $\mathrm{Fas}^{28}$ or granzyme B. ${ }^{29}$

Cell cycle progression is controlled by competing levels of cdks that are activated by cyclins. Cdks are also tightly regulated by inhibitory molecules called CDKIs, including p27/KIP1 and p21/CIP1/WAF1. p27/KIP1 regulates the G1/ $S$ transition and plays a protective role in cells subjected to apoptotic stimuli. For example, mesangial cells and fibroblasts derived from p27/KIP1 null mice are highly susceptible to apoptosis upon removal of growth factors, and cells can be rescued by reintroduction of $\mathrm{p} 27 / \mathrm{KIP} 1 .^{30}$ p27/KIP1 prevents drug-induced apoptosis in carcinoma and leukemic cell lines. ${ }^{31,32}$ The recent discovery that p27/ KIP1 is cleaved during apoptosis has yielded controversial results on its role in this process. Using human umbilical vein cells (HUVEC) deprived of growth factors as a model system to study apoptosis, Levkau and colleagues demonstrated that $\mathrm{p} 27 / \mathrm{KIP} 1$ is partially cleaved late in the apoptotic process. Levels of p27/KIP1 associated with cyclin $E$, cyclin $A$, or cdk2 were substantially reduced in apoptotic cells, and this correlated with the activation of cdk2 and enhanced apoptosis. ${ }^{33}$ Eymin and colleagues used etoposide-treated U937 human leukemic cells as a model system. ${ }^{34}$ Cells were arrested in S-phase using double thymidine block, and upon release of the arrest in the presence of etoposide, p27/KIP1 was cleaved. In contrast to the study of Levkau and colleagues, cleavage of p27/KIP1 was not associated with activation of cdk2. Surprisingly, transient transfection of individual p27/KIP1 cleavage products protected cells from etoposide-induced apoptosis, while stable expression of uncleavable p27/KIP1 mutants modestly increased the sensitivity of transfected cells to drug-induced apoptosis.

The CDKI p21/CIP1/WAF1 is required for apoptosis in several systems. Overexpression of p21/CIP1/WAF1 prevents apoptosis. Downregulation of p21/CIP1/WAF1 potentiates cell death, and cells can be rescued by reintroducing native $\mathrm{p} 21 / \mathrm{CIP} 1 / \mathrm{WAF} 1 .{ }^{35,36}$ The effect of cleavage of p21/CIP1/WAF1 on its function has been better characterized than for p27/KIP1. p21/CIP1/WAF1 is cleaved at several different sites. ${ }^{37}$ Cleavage at DHVD ${ }^{112}$ directly inhibits binding to proliferating cell nuclear antigen (PCNA), thus inhibiting DNA replication. ${ }^{38}$ In transfection experiments, the cleaved form of p21/CIP1/WAF1 no longer localizes to the nucleus ${ }^{33,38}$ and is incapable of arresting cells in $\mathrm{G} 1$ phase. ${ }^{38}$ Cleavage of p21/CIP1/WAF1 precedes the observed increase in cyclin $\mathrm{A} / \mathrm{cdk} 2$ activity. ${ }^{33}$ Finally, transfection of cleaved p21/CIP1/WAF1 is unable to suppress etoposide-induced apoptosis in comparison to wild-type p21/CIP1/WAF1, ${ }^{38}$ and expression of an uncleavable mutant of p21/CIP1/WAF1 in HUVEC cells suppresses apoptosis in response to growth factor withdrawal. These results suggest that intact p21/CIP1/WAF1 plays a largely protective role in apoptosis.

The PITSLRE kinases comprise a superfamily of p34/ cdc2-like kinases that have been implicated in tumorigenesis and apoptosis signaling. ${ }^{39}$ Apoptosis mediated by Fas or TNFR is accompanied by increased PITSLRE kinase activity. ${ }^{40}$ Several PITSLRE isoforms including p170 and p110 are specific targets of proteolysis by caspases during apoptosis. ${ }^{41}$ The cleavage site determined by initial mutational analysis predicts that cleavage should remove an $\mathrm{SH} 2$ domain and putative nuclear localization signals while preserving an intact kinase domain. ${ }^{41} \mathrm{~A}$ more detailed analysis of $\mathrm{p} 110$ cleavage sites has identified two additional cleavage sites in the amino terminus and confirms that the kinase domain remains intact following cleavage. ${ }^{42}$ Curiously, PITSLRE p110 is phosphorylated on serine residue(s) in response to Fas or TNFR activation, and the phosphorylated isoform appears to be more sensitive to in vivo cleavage by caspases. ${ }^{42}$ This is reminiscent of other caspases substrates whose cleavage is in part regulated by phosphorylation state, including $\mid \kappa B .{ }^{43}$ It is currently unknown whether PITSLRE kinase activity is directly activated by caspase cleavage. It has also not been established by expression of mutant or wild-type kinases whether PITSLRE kinases influence either the cell cycle or apoptosis, as is the case for the other cell cycle regulatory proteins described earlier. However, ectopic expression of a p50 mutant PITSLRE kinase resembling the cleaved form of p110 induces apoptosis. ${ }^{44}$ 


\section{(iv) Tripping up the competition III: regulation of components of the cell death receptor machinery}

Two kinases identified as components of the cell death machinery, RIPK1 and fyn, are caspase substrates. The protein kinase fyn associates directly with the TCR and with Fas. Since much more is known about the TCR signaling function of fyn, this molecule will be discussed in detail in a later section of this review.

RIPK1 is a death domain-containing kinase that associates with TRADD, a docking protein that associates with TNF-R1 upon engagement of the receptor by TNF. RIPK1 then activates NF- $\kappa$ B which mediates a competing cell survival pathway by initiating transcription of cell survival genes such as IEX-1. ${ }^{45}$ RIPK1 has recently been identified as a target of caspase 8 in response to Fas-, TRAIL-, and TNF-mediated cell death signals, but not following treatment with UV irradiation or exposure to corticosteroids or staurosporine. ${ }^{46}$ Although RIPK1 is cleaved upon Fas activation, Fas-mediated apoptosis does not require RIPK1. ${ }^{4,48}$ In response to TNF-R1 crosslinking, RIPK1 cleavage inhibits the nuclear translocation of $\mathrm{NF}-\kappa \mathrm{B}$ and potentiates the association of the carboxylterminal portion of RIP (RIPc) with TRADD and FADD. Ectopic expression of an uncleavable RIPK1 mutant inhibits receptor-mediated cell death.

Interestingly, the amino terminal portion of RIP (RIPn) contains the intact kinase domain yet plays no role in NF$\kappa \mathrm{B}$ activation, confirming previous reports that the kinase activity of RIPK1 is dispensable for RIPK1 function. ${ }^{49,50}$ Of interest, the related kinases RIPK2/CARDIAK ${ }^{51}$ and RIPK3 $^{52}$ both lack the consensus death domain motif present in RIPK1. Curiously, RIPK2 and RIPK3 both encode LXXD motifs that could serve as candidate caspase-8 cleavage sites. Although it has not yet been addressed whether these kinases are cleaved during cell death, the LXXD motifs are positioned such that cleavage at that site would liberate a carboxyl terminal fragment similar to the RIPK1 fragment that mediates cell death.

A recent series of elegant experiments by PimentelMuiños and Seed demonstrate that RIPK1 also plays a critical role in regulating the signal that is transduced through another TNF-family receptor, TNF-R2. ${ }^{53}$ TNF-R2 engagement triggers cell death through a pathway that requires RIPK1. However, when RIPK1 is absent (e.g., in Jurkat cell clones lacking RIPK1) addition of TNF activates $\mathrm{NF}-\kappa \mathrm{B}$ and promotes cell survival, most likely through TNFR2. Upon addition of TNF, RIPK1 ${ }^{-}$Jurkat cells, which express TNF-R1 but lack TNF-R2, undergo apoptosis when cotransfected with TNF-R2 and RIPK1. Importantly, proliferation of human peripheral blood $\mathrm{T}$ lymphocytes in response to interleukin-2 leads to the upregulation of RIPK1, which then 'bridges' the TNF-R and cell death machinery. ${ }^{53}$ These authors conclude that TNF signal transduction is context-dependent, and that the cell type and activation state of the cell may be critical determinants of an individual cell's response to TNF. When taken together with the identification of RIPK1 as a caspase 8 substrate, it appears that RIPK1 cleavage cripples one of the most important combatants in the death struggle, the
$\mathrm{NF}-\kappa \mathrm{B}$ pathway. This strongly suggests that RIPK1 acts as an important molecular 'sensor' or 'switch'53 - a 'referee' of life/death processes.

\section{(v) Stress management during cell death}

The activation of mitogen-activated protein kinase (MAPK) and stress-activated protein kinase (SAPK) pathways accompanies apoptosis and has been proposed to enhance, prevent, or amplify the apoptosis signal in a contextspecific manner. MAPK and SAPK pathways are particularly important in the death struggle since there are multiple points of entry for death signals, and an inherent capacity to amplify the initial signal by sequential activation or inactivation of other kinases in the pathway. Evidence exists for both caspase-dependent and caspase-independent cell death pathways that are mediated by MAPK and SAPK. The Ste20-like kinases Mst1 and Mst2 have recently been identified as caspase substrates that induce apoptosis through activation of JNK. Previous studies from several groups had identified a kinase activity migrating at $34 \mathrm{kD}$ by SDS-PAGE that was induced upon activation of Fas. Purification and sequencing of $\mathrm{V} 8$ digestion products of the kinase identified it as a proteolytic fragment of MST1/MST2. ${ }^{54}$ Both proteins were cleaved in response to a variety of different stressful stimuli when ectopically expressed in KB cells. MST1 and MST2 were resistant to cleavage in Jurkat cells in response to UV irradiation or following exposure to either etoposide or C-2 ceramide, suggesting that other factors might regulate cleavage of MST1 and MST2.

Cleavage of MST removes a carboxyl-terminal regulatory domain, which then stimulates the ability of MST to phosphorylate histone in an in vitro kinase assay. ${ }^{55}$ This fails to occur in vivo when an uncleavable mutant kinase is introduced into KB cells. ${ }^{54}$ The carboxyl-terminal domain of MST has previously been shown to be required for homoand hetero-dimerization. ${ }^{56}$ This raises the possibility that removal of the C-terminal interaction domain may directly inhibit the kinase activity of MST. It is also possible that removal of this domain regulates the amino-terminal kinase domain indirectly through an interaction with a regulatory $\mathrm{C}$ terminal heterodimeric partner, or by changing the localization of the activated kinase. Ectopic expression of MST induces apoptosis, and a kinase-dead mutant in HL60 cells inhibits both JNK activation and apoptosis. ${ }^{57}$ Similar results are obtained when BJAB or 293T cells are used. The physiologic targets of activated MST are unknown, although transfection of 293T cells with MST1 activates MKK7, MKK6, SAPK, and p38 MAPK. ${ }^{55}$

MEK kinases constitute a family of kinases that sequentially activate other members of the family to regulate kinases such as MAPK and JNK in response to cellular stress. MEKK-1 is a proximal constituent of this signaling pathway that is capable of inducing apoptosis when ectopically expressed. Following an apoptotic stimulus, MEKK-1 is phosphorylated and activated prior to its proteolytic degradation by caspase 3 , which generates a constitutively active kinase fragment. ${ }^{58}$ Transfection of wildtype MEKK-1 or the constitutively active kinase fragment induces apoptosis, while an uncleavable mutant or a 
Table 1 Signaling molecules are substrates for proteases that are activated during apoptosis

\begin{tabular}{|c|c|c|c|c|c|c|c|}
\hline Kinase & Substrate(s) & $\begin{array}{l}\text { Kinase } \\
\text { activity }\end{array}$ & $\begin{array}{l}\text { Apoptosis } \\
\text { effect }\end{array}$ & Function & $\begin{array}{c}\text { Caspase } \\
\text { cleavage sites }\end{array}$ & Protease & Ref \\
\hline DNA-PK & P53, SP1 $1^{104-106}$ & $\downarrow$ & $?$ & DNA repair & $\mathrm{DEVD}^{2712}$ & 3 & 22 \\
\hline MEKK-1 & MKK4, ?MEK $1^{107}$ & $\uparrow$ & $\uparrow \mathrm{U}, \mathrm{F}, \mathrm{K}, \mathrm{O}$ & Stress signaling & $\begin{array}{l}\text { DTVD }^{874} \\
\text { DTLD }^{68}\end{array}$ & 3 & 58,60 \\
\hline PAK2 & $\begin{array}{l}\text { MEK1, myosin } \\
\text { light chain, } \\
\text { P47 }\end{array}$ & $\uparrow$ & $\uparrow \mathrm{F}, \mathrm{K}$ & $\begin{array}{l}\text { Morphology, } \\
\text { membrane, } \\
\text { cytoskeletal } \\
\text { regulation }\end{array}$ & SHVD $^{212}$ & 3,8 & 9,10 \\
\hline CaMK IV & $\begin{array}{l}\text { CREB, ATF1, } \\
\text { AP-1, SRF, } \\
\text { CTF-1, synapsin I, } \\
\text { Rap-1b, }{ }^{112-118}\end{array}$ & $\downarrow$ & $?$ & $\begin{array}{l}\text { Transcriptional } \\
\text { activation }\end{array}$ & $\begin{array}{l}\mathrm{PAPD}^{176} \\
/ \mathrm{CG}^{201}\end{array}$ & $\stackrel{3}{3}$ & 74 \\
\hline CaMK $I 1 \alpha$ & $\begin{array}{l}\text { alpha-syntrophin, } \\
\text { dystrophin, EGF } \\
\text { receptor, } \\
\text { others }^{119,120}\end{array}$ & $\downarrow$ & $?$ & Pleiotropic & Unknown & $?$ & 74 \\
\hline CaMKK & CaMKs & $?$ & $?$ & Activates CaMKs & Unknown & $?$ & 74 \\
\hline Topoisomerase1 & $\begin{array}{l}\text { SR proteins, ?clk/ } \\
\text { sty kinases }\end{array}$ & $?$ & $?$ & $\begin{array}{l}\text { DNA replication, } \\
\text { SR kinase }\end{array}$ & $\begin{array}{l}\text { DDVD }^{146} \\
\text { EEEDD }^{170} \\
\text { PEDD }^{123}\end{array}$ & $\begin{array}{l}3 \\
3 \\
6\end{array}$ & 98 \\
\hline MST/Krs1 & $\begin{array}{l}\text { Unknown, ?MKK6, } \\
\text { MKK755 }\end{array}$ & $\uparrow$ & $\downarrow, \mathrm{K}$ & Stress signaling & DEMD $^{326}$ & 3 & 54,55 \\
\hline MST/Krs2 & Unknown & $\uparrow$ & $?$ & Stress signaling & DELD 322 & 3 & 54 \\
\hline SLK & $\begin{array}{l}\text { Unknown, ?JNK } \\
\text { pathway members }\end{array}$ & $\uparrow$ & $\uparrow, \mathrm{F}, \mathrm{K}, \mathrm{O}$ & $\begin{array}{l}\text { Cytoskeletal } \\
\text { regulation, actin } \\
\text { assembly }\end{array}$ & Unknown & 3 & 20 \\
\hline PITSLRE p170 & $\begin{array}{l}\text { Unknown } \\
\text { ?cyclins }\end{array}$ & $?$ & $?$ & $\begin{array}{l}\text { Cdc2-like kinase, } \\
\text { function unknown }\end{array}$ & Unknown & $?$ & 41 \\
\hline $\begin{array}{l}\text { PITSLRE kinase } \\
\text { p110 }\end{array}$ & $\begin{array}{l}\text { Unknown } \\
\text { ?cyclins }\end{array}$ & $(\uparrow)$ & $(\uparrow)$ & $\begin{array}{l}\text { Cdc2-like kinase, } \\
\text { function unknown }\end{array}$ & $\begin{array}{l}\text { YVPD }^{391} \\
\text { TEGD }^{387} \\
\text { DDRD }^{42}\end{array}$ & 3,1 & 41,42 \\
\hline RIPK1 & Unknown & $?$ & $\uparrow$ & $\begin{array}{l}\text { Death domain } \\
\text { kinase }\end{array}$ & LQLD $^{324}$ & 8 & 46 \\
\hline P59fyn & $\begin{array}{l}\text { ?WASP, CasL, Cbl, } \\
\text { PKC } \theta \text {, Pyk2, } \\
\text { Tctex-1 } 1^{121-126}\end{array}$ & $(\uparrow)$ & $?$ & $\begin{array}{l}\text { TCR signaling, } \\
\text { ?Fas signaling }\end{array}$ & $\begin{array}{l}\text { EESD }^{19} \\
\text { EERD }^{19}\end{array}$ & 3 , not 8 & 127 \\
\hline ZAP-70 & $\begin{array}{l}\text { LAT, SLP-76, } \\
\text { vav }^{128-130}\end{array}$ & $?$ & $?$ & TCR signaling & $\begin{array}{l}\text { aa306-326 } \\
\text { (not tested) }\end{array}$ & Calpain & 70 \\
\hline FAK & $\begin{array}{l}\text { Shc, paxillin, } \\
\text { p130 } \text { cas }^{131,132}\end{array}$ & $(\uparrow)$ & $\uparrow F$ & $\begin{array}{l}\text { Morphology, adhesion, } \\
\text { cytoskeletal regulation }\end{array}$ & $\begin{array}{l}\text { DQTD } \\
\text { VSW2 } \\
\text { VSW }^{704}\end{array}$ & $\begin{array}{l}3 \\
6\end{array}$ & 15 \\
\hline Raf-1 & MEK $1^{133,134}$ & $?$ & $?$ & Stress signaling & Unknown & $\begin{array}{c}? \\
\text { not } 3\end{array}$ & 17 \\
\hline Akt-1 & $\begin{array}{l}\text { Bad, Caspase } \\
9^{62,135}\end{array}$ & $?$ & $?$ & $\begin{array}{l}\text { Survival/ } \\
\text { proliferation }\end{array}$ & Unknown & $?$ & 17,61 \\
\hline $\operatorname{PKC} \delta$ & GAP $-43^{136}$ & $\uparrow$ & $\uparrow \mathrm{F}$ & Unknown & $\mathrm{DMQD}^{330}$ & 3 & 137 \\
\hline PKC $\theta$ & Unknown & $\uparrow$ & $\uparrow F$ & TCR signaling & $\mathrm{DEVD}^{354}$ & $\begin{array}{l}\text { 3, not } 2,6,7,9 \\
\text { Calpain }\end{array}$ & 73 \\
\hline $\mathrm{PKC} \zeta$ & hnRNPA $1^{138}$ & $\downarrow$ & $\uparrow U$ & $\begin{array}{l}\text { Cell growth } \\
\text { signaling }\end{array}$ & $\begin{array}{l}\text { EETD }^{210} \\
\text { DGVD }^{239}\end{array}$ & 3 & 139 \\
\hline $\mathrm{PKC} \mu$ & Unknown & $\uparrow$ & $?$ & Unknown & CQND $^{378}$ & 3 & 140 \\
\hline PRK2 & Unknown & $?$ & $?$ & Unknown & $\begin{array}{l}\text { DITD }^{117} \\
\text { DEVD }^{700}\end{array}$ & 3 & 141 \\
\hline PKN & $\begin{array}{l}\text { Neurofilament, } \\
\text { vimentin, actin, } \\
\text { caldesmon, glial } \\
\text { fibrillary acidic } \\
\text { protein }^{142-144}\end{array}$ & $\uparrow$ & $?$ & Unknown & $\begin{array}{l}\text { ATHD }^{108} \\
\text { KLED }^{451} \\
\text { DFLD }^{454} \\
\text { LGTD }^{558} \\
\text { TDSD }^{560}\end{array}$ & 3 & 145 \\
\hline $\begin{array}{l}\text { Wee1 } \\
\text { SRPK1 }\end{array}$ & $\begin{array}{l}\text { P34cdc2, cdk2 } 2^{146} \\
\text { SR proteins, ?clk/ } \\
\text { sty kinases }\end{array}$ & $\stackrel{\downarrow}{\downarrow}(\downarrow)$ & $\begin{array}{l}\downarrow 0 \\
? ?\end{array}$ & $\begin{array}{l}\text { Cell cycle } \\
\text { RNA splicing }\end{array}$ & $\begin{array}{l}\text { Unknown } \\
\text { ND }\end{array}$ & $\begin{array}{c}3,7,8 \\
8\end{array}$ & $\begin{array}{l}27 \\
\mathrm{MIP}\end{array}$ \\
\hline SRPK2 & $\begin{array}{l}\text { SR proteins, ?clk/ } \\
\text { sty kinases }\end{array}$ & $(\downarrow)$ & $?$ & RNA splicing & ND & 9 & MIP \\
\hline PP2A & Many ${ }^{102}$ & $\uparrow$ & $?$ & Pleiotropic & DEQD ${ }^{218}$ & 3 & 102 \\
\hline RasGAP & $\begin{array}{l}\text { Regulator of Ras } \\
\text { kinase }\end{array}$ & $?$ & $?$ & $\begin{array}{l}\text { Morphology, adhesion } \\
\text { cytoskeletal regulation }\end{array}$ & $\begin{array}{l}\text { DTVD } \\
\text { Not tested }\end{array}$ & 3 & 17 \\
\hline $\mathrm{Cbl}$ & $\begin{array}{l}\text { Kinase } \\
\text { adaptor }^{147,148}\end{array}$ & $?$ & $?$ & $\begin{array}{l}\text { Unknown, ?negative } \\
\text { regulator }\end{array}$ & Not tested & $\begin{array}{c}? \\
\text { not } 3\end{array}$ & 17 \\
\hline
\end{tabular}


Table 1 continued

\begin{tabular}{|c|c|c|c|c|c|c|c|}
\hline Kinase & Substrate(s) & $\begin{array}{l}\text { Kinase } \\
\text { activity }\end{array}$ & $\begin{array}{c}\text { Apoptosis } \\
\text { effect }\end{array}$ & Function & $\begin{array}{c}\text { Caspase } \\
\text { cleavage sites }\end{array}$ & Protease & Ref \\
\hline Cbl-b & $\begin{array}{l}\text { Kinase } \\
\text { adaptor }^{149,150}\end{array}$ & $?$ & $?$ & $\begin{array}{l}\text { Unknown, ?positive } \\
\text { regulator }\end{array}$ & Not tested & $\begin{array}{c}? \\
\text { not } 3\end{array}$ & 17 \\
\hline P27Kip1 & cdk2, cdk4, inhibitor & $\uparrow$ & $?$ & Cell cycle & $\begin{array}{l}\text { ESQD }^{108} \\
\text { DPSD }^{139}\end{array}$ & $3,6,7,8,11$ & 33,34 \\
\hline P21/Cip1/Waf1 & cdk inhibitor & $\uparrow$ & $\uparrow U, F$ & Cell cycle & $\begin{array}{l}\text { DHVD }^{112} \\
\text { SMTD }^{149}\end{array}$ & 3,7 & $33,37,38$ \\
\hline TCR $\zeta$ chain & TCR component & $(\downarrow)$ & $?$ & TCR signaling & Not tested & $3,7,9$ & 68, MIP \\
\hline
\end{tabular}

Kinases and other signaling molecules are listed in the first column (labeled 'Kinase'). Published substrates and appropriate references are listed in the second column (labeled 'Substrate(s)'). The effect of cleavage of the indicated signaling molecule on its kinase activity is presented in the third column (labeled 'Kinase activity') and is labeled with an arrow: increased, $\uparrow$; decreased, $\downarrow ;$ ? unknown. Arrows in parentheses $(\uparrow, \downarrow)$ indicate the predicted but untested effect on kinase activity following cleavage. The effect of kinase cleavage on regulation of apoptosis is indicated in the fourth column (labeled 'Apoptosis effect'): enhancement of apoptosis, $\uparrow$; prevention of apoptosis, $\downarrow$. The method used to demonstrate this effect is labeled as follows: $U$, transfection of an uncleavable mutant kinase; $F$, transfection of a kinase fragment; $\mathrm{K}$, transfection of a kinase-dead mutant; $\mathrm{O}$, overexpression of wild-type kinase; ?, untested. The fifth column (labeled 'Function') lists known functions of individual signaling molecules. The sixth column labeled 'Caspase cleavage sites' lists sites that have been directly identified, either by mutational analysis of the substrate $\mathrm{P} 1$ aspartic acid residue, or by peptide sequencing of proteolytic fragments. Column 7 (labeled 'Protease') lists caspases that have been implicated in the cleavage reaction. Caspases are listed by number. Bold numbers signify that the substrate is susceptible to direct cleavage by the indicated recombinant caspase or by purified calpain in an in vitro cleavage assay. The final column (labeled 'Ref') identifies the appropriate reference for the data presented in columns 6 and 7 . MIP, manuscript in preparation

kinase-dead mutant has reduced ability to promote cell death, probably by preventing the full activation of caspase 7.58,59 Interestingly, coexpression of the constitutively active MEKK-1 fragment and the caspase inhibitory protein p35 prevents apoptosis, albeit in a much less dramatic fashion than when the MEKK-1 fragment was replaced with wild-type protein. ${ }^{58}$ This suggests that MEKK1 requires caspase activation for its full proapoptotic function to be realized, and that MEKK-1 is capable of directly activating caspases on its own. A second caspase 3 cleavage site which relocalizes MEKK-1 to a triton-soluble compartment of the cell has recently been identified. ${ }^{60}$ The significance of this cleavage event remains unexplored.

Akt is a serine-threonine kinase that acts downstream of PI3-Ks and is thought to mediate a cell survival function in response to growth factors. Akt has recently been shown to be cleaved in vivo in Fas-stimulated Jurkat cells and UV-irradiated U937 cells, ${ }^{17}$ and in a cell-free system by addition of cytoplasmic extracts to intact nuclei in the presence of cytochrome c. ${ }^{61}$ Akt kinase activity decreases in Fas-stimulated Jurkat cells with kinetics that closely parallel its degradation. ${ }^{17}$ Although not cleaved in vitro by DEVD-directed caspases, Akt proteolysis in vivo is prevented in the presence of membrane-soluble caspase inhibitors. Addition of phosphatase inhibitors prevents activation of caspases 3 and 9, as well as Akt cleavage, suggesting that either the Akt substrate or more likely a component of the caspase machinery requires phosphorylation for full activity. This is consistent with a recent study demonstrating that phosphorylation of caspase 9 by Akt on ser $^{196}$ regulates its protease activity. ${ }^{62} \mathrm{~A}$ detailed analysis of the site of cleavage of Akt has not been performed as no cleavage product was evident by Western blot analysis. ${ }^{17,61}$ It remains to be determined whether Akt is cleaved directly by a caspase or by another downstream protease whose activation is caspasedependent. $\mathrm{Cbl}$ and $\mathrm{Cbl}-\mathrm{b}$, adaptor proteins that bind to $\mathrm{PI}-\mathrm{K}$, are also cleaved during apoptosis and presumably activate kinases such as Akt. ${ }^{17}$

\section{(vi) T cell receptor (TCR) signaling: new combatants or an unrecognized battlefield?}

$\mathrm{T}$ lymphocytes are activated in response to cross-linking of their TCRs by antigen complexed with MHC on the surface of APCs. The signal is transmitted by activation of several tyrosine kinases, including fyn and lck, which in turn phosphorylate several substrates (Table 1). A critical substrate in this pathway is the TCR $\zeta$ chain, which is tyrosine phosphorylated within cytoplasmic immunoreceptor tyrosine-based activation motifs (ITAMS). Following phosphorylation of the TCR $\zeta$ chain, the ZAP. 70 tyrosine kinase is then recruited to the TCR complex where it is phosphorylated and activated. Disruption of this pathway prevents the transmission of a signal, altering the function and potentially the fate of the 'activated' $T$ cell. Indeed, targeted disruption of the murine genes encoding several components of this pathway lead to profound defects in $T$ cell signaling and lymphocyte development (reviewed in ${ }^{63}$ ).

Three well-characterized molecules involved in transmitting this signal have now been identified as targets for site-specific proteases. Fyn is a src-family kinase that is rapidly activated following TCR ligation. Interestingly, fyn also associates directly with Fas, and fyn-/fyn-mice are resistant to Fas-mediated apoptosis, suggesting that fyn may also be involved in transmitting signals through death receptors. ${ }^{64,65}$ Fyn is cleaved in vivo in response to several different apoptotic stimuli, and in vitro by caspase 3. Following cleavage in vivo, which liberates the $\mathrm{N}$-terminal palmitoylation and myristoylation sites from the remainder of the molecule, fyn relocalizes to the cytoplasm. The $\mathrm{N}$-terminal domain of fyn encompassing aa $1-19$ is absolutely required for interaction of fyn with ITAMs. This domain is also required for fyn to interact with one of its substrates. Tctex-1, a component of the motor unit that is required for spindle localization and the separation of centrosomes during mitosis. ${ }^{66}$ Thus Tctex1 , in addition to other cytoplasmic substrates of fyn, is an attractive target of disrupted fyn function following caspase 
cleavage. It is unknown whether the kinase activity of fyn is directly affected by cleavage, although the known structure of fyn suggests that the kinase activity should be preserved.

Although it does not possess intrinsic kinase activity, the TCR $\zeta$ chain is an important component of the TCR signaling machinery. TCR $\zeta$ chain expression is markedly decreased in tumor-infiltrating lymphocytes (TILs), and it has been suggested that this observation underlies the immune deficits exhibited by cancer patients. ${ }^{67}$ The mechanism of TCR $\zeta$ downregulation is obscure but may be attributable to caspase cleavage. TCR $\zeta$ is cleaved in vivo in PBLs and Jurkat $T$ cells exposed to etoposide or staurosporine, or in response to Fas activation. Degradation can be prevented by overexpression of bcl-2 or CrmA, or by coincubation with soluble peptide caspase inhibitors. ${ }^{68}$ The protein is also cleaved in vitro by caspases 3 and $7,{ }^{68}$ and by caspase 9 (our unpublished data). The cleavage site(s) have not yet been established; however several potential sites have been identified which would eliminate 1,2, or all 3 ITAMs from the molecule, depending on the site of caspase cleavage. Since phosphorylation of ITAMs is thought to occur in a sequential and/or additive manner, it is likely that TCR $\zeta$ cleavage at individual sites serves to modulate the TCR signal, or to determine a threshold for $T$ cell activation. ${ }^{69}$

ZAP-70 has recently been shown to be a target of calpain, ${ }^{70}$ a noncaspase protease that is activated during cell death. ZAP-70 cleavage correlates with the observed downregulation of ZAP-70 and TCR $\zeta$ chain from the surface of the cell, with a peak at approximately $2 \mathrm{~h}$ following stimulation with antigen. The disappearance of ZAP-70 is inhibited by the src-kinase inhibitor PP1; moreover, ZAP-70 and TCR $\zeta$ chain degradation is prevented by preincubation of cells with calpain inhibitors such as PD150606 and calpeptin but not by bafilomycin A1, a lysosome inhibitor. ZAP-70 is efficiently cleaved in vitro by calpain, generating a single $35 \mathrm{kD}$ cleavage product that is also observed when ZAP-70 is overexpressed in vivo. Taken together, these results demonstrate that ZAP-70 is an in vivo and in vitro target of calpain, and that TCR $\zeta$ chain degradation in the lysosome requires intact ZAP-70. The physiologic role of this process remains unclear, although it is possible that ZAP-70 cleavage may prevent sustained TCR signaling. Although not addressed in this study, it has been proposed that ZAP70 cleavage by calpain is a marker for an early form of cell death. ${ }^{71,72}$ Calpain is known to cleave other signaling molecules during apoptosis, including CamK IV and $\operatorname{PKC} \theta .^{73,74}$

\section{(vii) Resetting the apoptotic switch through RNA splicing of apoptosis regulatory molecules: changing the rules of battle after the battle starts}

The apoptosis threshold is controlled by multiple mechanisms in cells. First, relative levels of proapoptotic (e.g., Ich-1 $1_{L}$ and bcl- $\mathrm{x}_{\mathrm{S}}$ ) and antiapoptotic (e.g., bcl-2 and bcl- $\mathrm{x}_{\mathrm{L}}$ ) molecules set a threshold that must be overcome for a given stimulus to irreversibly activate the cell death pathway. ${ }^{75,76}$ Second, stressed cells respond to stimuli by stimulating kinase pathways (e.g., JNK and MAPK), ultimately converging in the nucleus where transcriptional activation of antiapoptotic genes such as IEX-1 occurs. ${ }^{7,45,77}$ Third, it is now widely accepted that apoptosis is regulated at the level of mRNA splicing. For example, it has been shown that cells expressing the larger splice variant of the bcl-x gene $\left(b c l-x_{L}\right)$ are protected against cell death, while cells expressing the short form lacking the highly conserved $\mathrm{BH} 1$ and $\mathrm{BH} 2$ interaction domains $\left(\mathrm{bcl}-\mathrm{x}_{\mathrm{S}}\right)$ have an increased susceptibility to cell death. ${ }^{75,76,78,79}$ Similar regulation has been described for the C. elegans ced-4 gene product, ${ }^{75,76,78-80}$ for the death domain-containing receptor LARD, ${ }^{75,76,78-81}$, and for caspase 2 (Nedd2/Ich1). ${ }^{82}$ Overall, more than 30 apoptosis effectors that are regulated at the level of alternative mRNA splicing have been described. ${ }^{83}$ However, it is unknown how levels of the opposing factors are determined, nor is it known whether relative levels of antagonistic factors can change in a given cell in response to external stimuli.

The observation that many autoantigens (e.g., La, ${ }^{84} \mathrm{U} 1-$ $70 \mathrm{kD},{ }^{85}$ and the $72 \mathrm{kD}$ component of the signal recognition particle, SRP $72^{86}$ ) are cleaved by caspases during cell death led our lab to use human autoimmune sera to identify proteins that are phosphorylated during apoptosis. ${ }^{87}$ These experiments led to the discovery of a novel kinase pathway involved in the phosphorylation of an important family of RNA splicing factors, termed serine arginine (SR) proteins, during apoptosis. ${ }^{88} \mathrm{SR}$ proteins comprise a family of premRNA splicing factors that regulate constitutive and alternative mRNA splicing. ${ }^{89}$ The splicing activity of SR proteins is modulated by phosphorylation of their SR domains. ${ }^{89}$ To date at least six kinases have been described that are capable of phosphorylating SR proteins in human cells. These include SRPK1 and SRPK2; Clk/ Sty 1, 2, and 3; and topoisomerase I. $^{90-96}$ It is currently unknown which of the six SRPKs are relevant in the SRPK pathway, nor is it known how they are activated in response to stressful stimuli.

An intriguing possibility is that one or more SRPKs might be activated or dysregulated following proteolysis by caspases. We have demonstrated that caspase cleavage of several SRPKs does indeed occur and may play an important role in regulating the phosphorylation of SR proteins that is observed during apoptosis. SRPK1 and SRPK2 are both cleaved in an in vitro cleavage assay, and SRPK1 is cleaved in vivo following a wide variety of apoptotic stimuli (manuscript in preparation). Another SRPK, topoisomerase I, is also cleaved in response to apoptotic stimuli. ${ }^{97}$ In addition to its DNA unwinding activity, topoisomerase I surprisingly possesses SR protein kinase activity. ${ }^{96}$ Purified topoisomerase I phosphorylates several SR proteins including ASF/SF2 and $\mathrm{SC} 35$, and the kinase activity is inhibited by addition of the topoisomerase inhibitor camptothecin in the presence of DNA. ${ }^{96}$ Topoisomerase $I$ is cleaved at later times than many other antigens following caspase activation, which is thought to result from cleavage at unconventional sites. ${ }^{98}$ Unlike other kinases such as fyn which relocalize following cleavage, topoisomerase I remains associated with chromatin. The DNA relaxing 
function of topoisomerase remains unperturbed following cleavage, while the SR kinase activity of the fragments has not yet been examined. Taken together, these results implicate SR proteins and SRPKs as potential mediators of alternative splicing and apoptosis, a concept that is further supported by the recent discovery that overexpression of SR proteins can 'reset' the apoptotic threshold by regulating alternative splicing of the Ich-1 mRNA. ${ }^{99}$

\section{(viii) Signaling molecules with pleiotropic functions}

PKCs play important roles in a variety of intracellular signaling pathways including TCR activation and regulation of cell proliferation. ${ }^{100}$ Three of the eleven known members of the PKC family (PKC $\delta, \operatorname{PKC} \theta$ and $\mathrm{PKC} \zeta$,) are cleaved by caspases during apoptosis, as are two related kinases (PKR2, and PKN). Interestingly, $\mathrm{PKC} \beta$, which is not a caspase substrate, is proteolyzed by calpain in leukocytes incubated with the apoptosis-promoting second messenger ceramide and may represent yet another PKC family member that is regulated by proteolysis in response to cellular stressors. ${ }^{101}$ With the exception of PKN, the functional effects of cleavage of members of this kinase family on apoptosis have been well summarized in a recent review and will not be discussed herein. ${ }^{5}$

CaMK IV is a serine-threonine kinase with restricted tissue distribution and a high degree of homology to CaMK II. ${ }^{74}$ CaMK IV has been implicated in activation of a number of important transcription factors (Table 2). Like the situation for other kinases such as DNA-PK and $\mathrm{PKC} \zeta$, inhibition of CaMK kinase activity is associated with apoptosis. CaMK IV but not CaMK II $\beta$ is rapidly cleaved during cell death with kinetics that precede the observed decrease in CaMK activity. ${ }^{74}$ In addition to CaMK IV, CaMK Il $\alpha$ and the upstream activator CaMK kinase (CaMKK) are also cleaved in vivo in SH-SY5Y cells exposed to staurosporine, a finding that is reminiscent of the observed sequential cleavage of several MAPK components such as MEKK-1 and MSTs. CaMK IV is also cleaved by calpain to a $40 \mathrm{kD}$ fragment in a manner that is inhibited by a calpain inhibitor, both in vivo and in vitro.

Although it is not a kinase, the protein phosphatase $2 \mathrm{~A}$ (PP2A) is the most abundant mammalian phosphatase and deserves mention for its potentially important role in regulating many of the signaling pathways described above. The regulatory $\alpha$ subunit of PP2A was found to interact specifically with caspase 3 in a yeast two hybrid screen. ${ }^{102}$ Although a stable complex between caspase 3

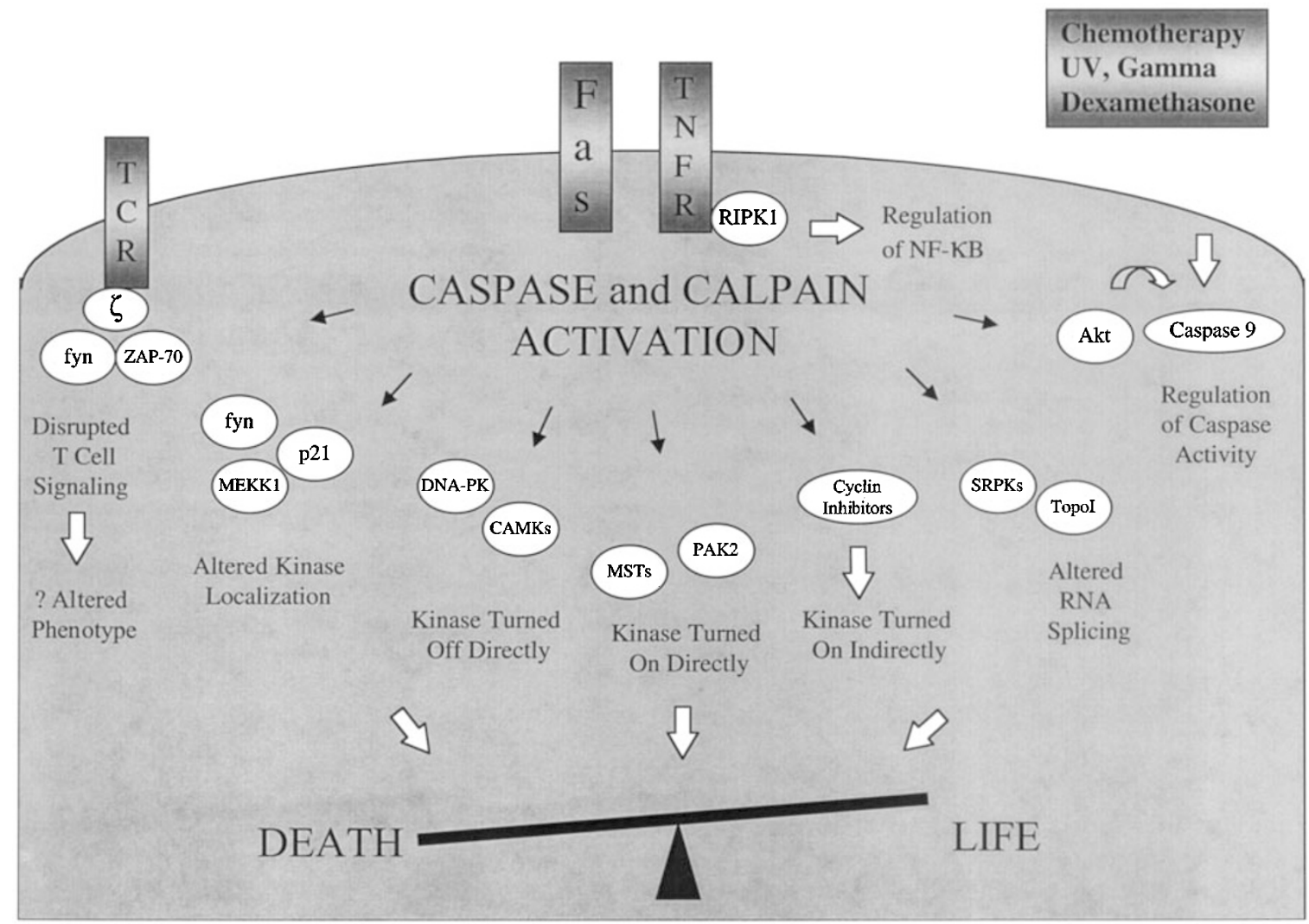

Figure 1 Cleavage of signaling molecules mediates life and death decisions. Death pathways are turned on through death receptors such as Fas or TNF-R, or by exogenous stimuli (e.g., chemotherapy, irradiation, or steroids), generating active proteases that include calpain and caspases. Signaling molecules described in this review are important substrates of these proteases and integrate multiple signals to determine the ultimate fate of the cell. Although not shown in the figure, relative levels of molecules such as RIPK1, IAPS, FAP, FLIPS FLICE, crmA, and other apoptosis inhibitory molecules play critical roles in this decision. Abbreviations are listed in the beginning of the review 
Table 2 Signaling molecules that are not caspase substrates

\begin{tabular}{lclr}
\hline Signaling molecule & Reference & Signaling molecule & Reference \\
\hline P56 Ick & 127 & MAPK phosphatase-1 & 17 \\
P72 syk & 127 & C-myc & 17 \\
$14-3-3$ & 17 & P38 & 17 \\
C-abl & 17 & PI3-K p85 & 17 \\
Adenylyl cyclase V & 17 & PI3-K p110 & 17 \\
cdc2 & 17 & Phospholipase C- $\gamma 1$ & 17 \\
E1B & 17 & B-raf & 17 \\
ERK1/ERK2 & 17 & SEK-1 & 17 \\
Grb2 & 17 & src & 17 \\
GRK2 & 17 & TRAF-1 & 17 \\
JNK-1 & 17 & FAST kinase & \\
MEK-1 & 17 & Clk-1 & (our unpublished data) \\
MEK-2 & 17 & Clk-2 & (our unpublished data) \\
MEKK2 & 17 & Clk-3 & (our unpublished data) \\
PITSLRE p90 & 41 & Clk-4 & (our unpublished data) \\
cdc25A & 27 & PAK3 & (our unpublished data) \\
cdc25C & 27 & PKC $\varepsilon$ & 5 \\
cdc16/APC6 & 27 & PKC $\lambda / 1$ & 10 \\
Plk-1 & 27 & PKC $\alpha$ & 73 \\
p55cdc & 27 & PKC $\beta$ & 139 \\
& & & 73 \\
\hline
\end{tabular}

Molecules listed in the table have been directly tested for their susceptibility to caspase-mediated cleavage, either by utilizing protein-specific antibodies in Western blot analysis (comparing lysates prepared from untreated and apoptotic cells), or by an in vitro caspase cleavage assay

and PP2A could not be demonstrated, PP2A $\alpha$ is a specific substrate for caspase 3 in vitro. ${ }^{102}$ PP2A activity is increased in vivo and in vitro in response to apoptotic stimuli, and this correlates temporally with cleavage of the inhibitory PP2A $\alpha$ subunit. Given the potentially large number of signaling pathways that are regulated by $P P 2 A$, cleavage of the PP2A $\alpha$ subunit may serve an important global function in the cell death process.

\section{Concluding remarks}

Signaling molecules such as kinases, phosphatases, adaptor molecules, and kinase inhibitors form an interesting group of substrates that are well-positioned to play a critical role in the execution phase of apoptosis. They may play an even greater role in the 'sensing' phase of cell death, ultimately determining cell fate. The mechanisms by which cleavage of these molecules regulate cell death are as varied as the diverse pathways that are affected (Figure 1). For example, molecules such as fyn, MEKK-1, and p21/ CIP1/WAF1 change their subcellular localization following cleavage. Presumably their absence from the locale where they usually function, or their presence at a location where they normally are not found or where unusual substrates exist, mediates their role in apoptosis signaling. Some kinases such as DNA-PKcs and CaMKs are turned off, others such as MSTs and PAK2 are directly activated, and still others are indirectly activated (e.g., by inactivation of cyclin inhibitors) when cleaved by caspases. At least one kinase, RIPK1, does not even require an active kinase domain to regulate apoptosis and presumably does so by enhancing TRADD and FADD interactions. SR protein kinases such as SRPK1 and topoisomerase I are believed to reset the apoptosis threshold that must be overcome by changing alternative splicing patterns of mRNAs encoding apoptosis regulatory molecules. Finally, caspase 9 is negatively regulated upon phosphorylation by Akt kinase, offering yet another level of intricacy to this already complex system.

An important point that needs to be made is that activation of caspases in response to stressful stimuli is not universally associated with lethality. In fact, many cellular and viral proteins capable of inhibiting discrete steps in the caspase cascade are emerging and include IAPS, FAP, FLIPS FLICE, and crmA (reviewed in ${ }^{103}$ ). Increased expression of such molecules can not only prevent apoptosis but may also permit partial activation of distinct caspase pathways. For example, enhanced expression of the short form of caspase 2 (a procaspase 2 inhibitor) or of IAPs (caspase 3 inhibitors) would be expected to prevent activation of these important distal caspases in response to Fas activation or UV irradiation, but could still allow full activation of proximal caspases such as caspase 8 and caspase 9, respectively. If this occurred, cleavage of signaling molecules such as RIPK1, PAK2, Wee1, SRPK1, and SRPK2 would still occur in a cell that was presumably incapable of completing the death program because of caspase inhibition at a distal point in the cascade. Similarly, $\mathrm{T}$ cell activation in the presence of a distal caspase inhibitor would be thwarted by the proximal cleavage of TCR $\zeta$ by caspase 9 . While highly speculative, such a mechanism might in part explain such clinicallyimportant phenomena as chemotherapy resistance of tumor cells (e.g., through RIPK1 or SRPK cleavage), loss of T cell tolerance, and development of $\mathrm{T}$ cell anergy (e.g., through loss of TCR signaling following TCR $\zeta$ cleavage). As more signaling molecules emerge as caspase substrates, and as other cellular and viral caspase inhibitors are discovered, it should be possible to better understand the life and death struggle faced by cells. 


\section{Note added in proof}

Two additional kinases have been reported as caspase substrates since the submission of this manuscript. They include hematopoietic progenitor kinase 1 (HPK1), Chen YR, Meyer CF, Ahmed B, Yao Z and Tan TH (1999), Caspase-mediated cleavage and functional changes of HPK1, Oncogene 18: 7370-7377; and p130cas, Kook S, Shim SR, Choi SJ, Ahnn J, Kim JI, Eom SH, Jung YK, Paik SG and Song WK (2000), Caspase-mediated cleavage of p130cas in etoposide-induced apoptotic rat-1 cells, Mol. Biol. Cell 11: 929-939.

\section{Acknowledgements}

The authors thank WJ van Venrooij, WGJ Degen, GJM Pruijn, members of the Anderson laboratory, and participants of the 1999 Bertine Koperberg Conference in Nijmegen, The Netherlands for helpful comments and stimulating discussions. The authors regret failing to include the work of others that could not be referenced due to space limitations. Dr. Utz's work was supported in part by the Arthritis Foundation, National Institutes of Health Grant K08AI01521, the Arthritis National Research Foundation, the Scleroderma Foundation, Inc., and laboratory startup funding provided by Stanford University. Dr. Anderson's work was funded by the Arthritis Foundation, National Institutes of Health Grants Al33600 and CA67929, the Peabody Foundation, and the Leukemia Society of America.

\section{References}

1. Andrade F, Roy S, Nicholson D, Thornberry N, Rosen A and Casciola-Rosen LA (1998) Granzyme B directly and efficiently cleaves several downstream caspase substrates: implications for CTL-induced apoptosis. Immunity 8: $451-460$

2. Casciola-Rosen LA, Andrade F, Ulanet D, Wong W and Rosen A (1999) Cleavage by granzyme $B$ is strongly predictive of autoantigen status. Implications for initiation of autoimmunity. J. Exp. Med. 190: 815-826

3. Utz PJ, Gensler TJ and Anderson P (2000) Death, autoantigen modifications, and tolerance. Arthritis Res. 2: 101-114

4. Utz PJ and Anderson P (1998) Posttranslational modifications, apoptosis, and bypass of tolerance to autoantigens. Arthritis Rheum. 41: 1152-1160

5. Bokoch G (1998) Caspase-mediated activation of PAK2 during apoptosis: proteolytic kinase activation as a general mechanism of apoptotic signal transduction. Cell Death Differ. 5: 637-645

6. Nicholson D and Thornberry N (1997) Caspases: killer proteases. TIBS 22: 299-306

7. Anderson P (1997) Kinase cascades regulating entry into apoptosis. Microbiol. Mol. Biol. Rev. 61: 33-46

8. Kerr J, Wyllie A and Currie A (1972) Apoptosis: a basic biological phenomenon with wide-ranging implications in tissue kinetics. Br. J. Cancer 26: 239-257

9. Rudel T and Bokoch G (1997) Membrane and morphological changes in apoptotic cells regulated by caspase-mediated activation of PAK2. Science 276: $1571-1574$

10. Lee N, MacDonald H, Reinhard C, Halenbeck R, Roulston A, Shi T and Williams $L$ (1997) Activation of hPAK65 by caspase cleavage induces some of the morphological and biochemical changes of apoptosis. Proc. Natl. Acad. Sci. USA 94: $13642-13647$

11. Schlaepfer D, Hauck $C$ and Sieg D (1999) Signaling through focal adhesion kinase. Prog. Biophys. Mol. Biol. 71: 435-478

12. van de Water B, Nagelkerke J and Stevens J (1999) Dephosphorylation of focal adhesion kinase (FAK) and loss of focal contacts precede caspase-mediated cleavage of FAK during apoptosis in renal epithelial cells. J. Biol. Chem. 274: $13328-13337$

13. Chan P, Lai J, Cheng C, Tang M, Chiu C and Chen H (1999) Suppression of ultraviolet irradiation-induced apoptosis by overexpression of focal adhesion kinase in Madin-Darby canine kidney cells. J. Biol. Chem. 274: 26901-26906

14. Wen L, Fahrni J, Troie S, Guan J, Orth K and Rosen G (1997) Cleavage of focal adhesion kinase by caspases during apoptosis. J. Biol. Chem. 272: 26056 26061
15. Gervais F, Thornberry N, Ruffolo S, Nicholson D and Roy S (1998) Caspases cleave focal adhesion kinase during apoptosis to generate FRNK-like polypeptide. J. Biol. Chem. 273: 17102-17108

16. Wen L, Madani K, Martin G and Rosen G (1998) Proteolytic cleavage of ras GTPase-activating protein during apoptosis. Cell Death Differ. 5: 729-734

17. Widmann C, Gibson S and Johnson G (1998) Caspase-dependent cleavage of signaling proteins during apoptosis. J. Biol. Chem. 273: 7141-7147

18. Henkemeyer M, Rossi D, Holmyard D, Puri M, Mbamalu G, Harpal K, Shih T, Jacks T and Pawson T (1995) Vascular system defects and neuronal apoptosis in mice lacking ras GTPase-activating protein. Nature 377: 695-701

19. McGlade J, Brunkhorst B, Anderson D, Mbamalu G, Settleman J, Dedhar S, Rozakis-Adcock M, Chen L and Pawson T (1993) The N-terminal region of GAP regulates cytoskeletal structure and cell adhesion. EMBO J. 12: 3073-3081

20. Sabourin L, Seale P, Wagner J and Rudnicki M (2000) Caspase 3 cleavage of the Ste20-related kinase SLK releases and activates an apoptosis-inducing kinase domain and an actin-disassembling region. Mol. Cell. Biol. 20:684-696

21. Sabourin L and Rudnicki M (1999) Induction of apoptosis by SLK, a Ste20related kinase. Oncogene 18: $7566-7575$

22. Casciola-Rosen LA, Anhalt GJ and Rosen A (1995) DNA-dependent protein kinase is one of a subset of autoantigens specifically cleaved early during apoptosis. J. Exp. Med. 182: 1625-1634

23. Song Q, Lees-Miller S, Kumar S, Zhang Z, Chan D, Smith G, Jackson S, Alnemri E, Litwack G, Khanna K and Lavin M (1996) DNA-dependent protein kinase catalytic subunit: a target for an ICE-like protease in apoptosis. EMBO J. 15: $3238-3246$

24. Le Romancer M, Cosulich S, Jackson S and Clarke P (1996) Cleavage and inactivation of DNA-dependent protein kinase catalytic subunit during apoptosis in Xenopus egg extracts. J. Cell Sci. 109: 3121-3127

25. Molz L, Booher R, Young P and Beach D (1989) cdc2 and the regulation of mitosis: six interacting mcs genes. Genetics 122: 773-782

26. Morgan D (1995) Principles of CDK regulation. Nature 374: 131-134

27. Zhou B, Li H, Yuan J and Kirschner M (1998) Caspase-dependent activation of cyclin-dependent kinases during Fas-induced apoptosis in Jurkat cells. Proc. Natl. Acad. Sci. USA 95: 6785-6790

28. Yao S, McKenna K, Sharkis S and Bedi A (1996) Requirement of p34cdc2 kinase for apoptosis mediated by the Fas/APO-1 receptor and interleukin 1beta-converting enzyme-related proteases. Cancer Res. 56: 4551-4555

29. Chen G, Shi L, Litchfield D and Greenberg A (1995) Rescue from granzyme Binduced apoptosis by Wee1 kinase. J. Exp. Med. 181: 2295-2300

30. Hiromura K, Pippi J, Fero M, Roberts J and Shankland S (1999) Modulation of apoptosis by the cyclin-dependent kinase inhibitor p27(Kip1). J. Clin. Invest. 103: $597-604$

31. Eymin B, Haugg M, Droin N, Sordet O, Dimanche-Boitrel M and Solary E (1999) p27Kip1 induces drug resistance by preventing apoptosis upstream of cytochrome $c$ release and procaspase- 3 activation in leukemic cells. Oncogene 18: 1411-1418

32. Dimanche-Boitrel M, Micheau O, Hamman A, Haugg M, Eymin B, Chauffert B and Solary $E$ (1998) Contribution of the cyclin-dependent kinase inhibitor p27KIP1 to the confluence-dependent resistance of HT29 human colon carcinoma cells. Int. J. Cancer 77: 796-802

33. Levkau B, Koyama H, Raines E, Clurman B, Herren B, Orth K, Roberts J and Ross $R$ (1998) Cleavage of p21/Cip1/Waf1 and p27Kip1 mediates apoptosis in endothelial cells through activation of Cdk2: role of a caspase cascade. Mol. Cell 1: $553-563$

34. Eymin B, Sordet O, Droin N, Munsch B, Haugg M, van de Craen M, Vandenabeele P and Solary E (1999) Caspase-induced proteolysis of the cyclin-dependent kinase inhibitor p27kip1 mediates its anti-apoptotic activity. Oncogene 18: 4839-4847

35. Sheikh M, Garcia M, Zhan Q, Liu Y and Fornace A (1996) Cell cycleindependent regulation of p21Waf1/Cip1 and retinoblastoma protein during okadaic acid-induced apoptosis is coupled with induction of Bax protein in human breast carcinoma cells. Cell Growth Differ. 7: 1599-1607

36. Wang Jand WalshK (1996) Resistance to apoptosis conferred by Cdk inhibitors during myocyte differentiation. Science 273: 359-361

37. Park J, Kim K, Kim S and Lee S (1998) Caspase 3 specifically cleaves p21WAF1/CIP1 in the earlier stage of apoptosis in SK-HEP-1 human hepatoma cells. Eur. J. Biochem. 257: 242-248 
38. Zhang Y, Fujita N and Tsuruo T (1999) Caspase-mediated cleavage of p21Waf1/Cip1 converts cancer cells from growth arrest to undergoing apoptosis. Oncogene 18: 1131-1138

39. Lahti J, Xiang J and Kidd V (1995) The PITSLRE protein kinase family. Prog. Cell Cycle Res. 1: 329-338

40. Lahti J, Xiang J, Heath L, Campana D and Kidd V (1995) PITSLRE protein kinase activity is associated with apoptosis. Mol. Cell. Biol. 15: 1-11

41. Beyaert R, Kidd V, Cornelis S, van de Craen M, Denecker G, Lahti J, Gururajan R, Vandenabeele P and Friers W (1997) Cleavage of PITSLRE kinase by ICE/ CASP-1 and CPP32/CASP-3 during apoptosis induced by tumor necrosis factor. J. Biol. Chem. 272: 11694-11697

42. Tang D, Gururajan R and Kidd V (1998) Phosphorylation of PITSLRE p110 isoforms accompanies their processing by caspases during Fas-mediated cell death. J. Biol. Chem. 273: 16601-16607

43. Barkett M, Xue D, Horvitz H and Gilmore T (1997) Phosphorylation of IkappaBalpha inhibits its cleavage by caspase CPP32 in vitro. J. Biol. Chem. 272: 29419-29422

44. Bunnell B, Heath L, Adams D, Lahti J and Kidd V (1990) Increased expression of a 58-kDa protein kinase leads to changes in the $\mathrm{CHO}$ cell cycle. Proc. Natl. Acad. Sci. USA 87: 7467-7471

45. Wu M, Ao Z, Prasad K, Wu R and Schlossman S (1998) IEX-1L, an apoptosis inhibitor involved in NF- $\kappa$ B-mediated cell survival. Science 281: $998-1001$

46. Lin Y, Devin A, Rodriguez Y and Liu Z (1999) Cleavage of the death domain kinase RIP by caspase-8 prompts TNF-induced apoptosis. Genes Dev. 13: $2514-2526$

47. Stanger B, Leder P, Lee T, Kim E and Seed B (1995) RIP: a novel protein containing a death domain that interacts with Fas/APO-1 (CD95) in yeast and causes cell death. Cell 81: 513-523

48. Kelliher M, Grimm S, Ishida Y, Kuo F, Stanger B and Leder P (1998) The death domain kinase RIP mediates the TNF-induced NF-kappaB signal. Immunity 8: 297-303

49. Ting A, Pimental-Muiños F and Seed B (1996) RIP mediates tumor necrosis factor receptor-1 activation of NF- $\kappa$ B but not Fas/Apo-1-initiated apoptosis. EMBO J. 15: 6189-6196

50. Hsu H, Huang J, Shu H, Baichwal V and Goeddel D (1996) TNF-dependent recruitment of the protein kinase RIP to the TNF receptor-1 signaling complex. Immunity 4: 387-396

51. Thome M, Hofmann K, Burns K, Martinon F, Bodmer J, Mattmann C and Tschopp J (1998) Identification of CARDIAK, a RIP-like kinase that associates with caspase-1. Curr. Biol. 8: 885-888

52. Yu P, Huang B, Shen M, Quast J, Chan E, Xu X, Nolan G, Payan D and Luo Y (1999) Identification of RIP3, a RIP-like kinase that activates apoptosis and NF$\kappa$ B. Curr. Biol. 9: 539-542

53. Pimentel-Muiños F and Seed B (1999) Regulated commitment of TNF receptor signaling: a molecular switch for death or activation. Immunity 11: 783-793

54. Lee K, Murakawa M, Nishida E,Tsubuki S, Kawashima S, Sakamaki K and Yonehara S (1998) Proteolytic activation of MST/Krs, STE20-related protein kinase, by caspase during apoptosis. Oncogene 16: 3029-3037

55. Graves J, Gotoh Y, Draves K, Ambrose D, Han D, Wright M, ChernoffJ, Clark E and Krebs $E$ (1998) Caspase-mediated activation and induction of apoptosis by the mammalian Ste20-like kinase Mst1. EMBO J. 17: 2224-2234

56. Creasy C, Ambrose D and Chernoff J (1996) The Ste20-like protein kinase, Mst1, dimerizes and contains an inhibitory domain. J. Biol. Chem. 271:2104921053

57. Watabe M, Kakeya H and Osada H (1999) Requirement of protein kinase (Krs/ MST) activation for MT-21-induced apoptosis. Oncogene 18: 5211-5220

58. Widmann C, Gerwins P, Johnson N, Jarpe M and Johnson G (1998) MEK kinase-1, a substrate for DEVD-directed caspases, is involved in genotoxininduced apoptosis. Mol. Cell. Biol. 18: 2416-2429

59. Cardone M, Salvesen G, Widmann C, Johnson G and Frische S (1997) The regulation of anoikis: MEKK-1 activation requires cleavage by caspases. Cell 90: $315-323$

60. Deak J, Cross J, Lewis M, Qian Y, Parrott L, Distelhorst C and Templeton D (1998) Fas-induced proteolytic activation and intracellular redistribution of the stress-signaling kinase MEKK1. Proc. Natl. Acad. Sci. USA 95: 5585-5600

61. Francois F and Grimes M (1999) Phosphorylation-dependent Akt cleavage in neural cell in vitro reconstitution of apoptosis. J. Neurochem. 73: 1773-1776
62. Cardone M, Roy N, Stennike H, Salvesen G, Franke T, Stanbridge E, Frische S and Reed J (1998) Regulation of cell death protease caspase-9 by phosphorylation. Science 282: 1318-1321

63. Alberola-Ila J, Takaki S, Kerner J and Perlmutter R (1997) Differential signaling by lymphocyte antigen receptors. Ann. Rev. Immunol. 15: 125-154

64. Atkinson E, Ostergaard H, Kane K, Pinkowski M, Caputo A, Olszowy M and Bleakley C (1996) A physical interaction between the cell death protein Fas and the tyrosine kinase p59fynT. J. Biol. Chem. 271: 5968-5971

65. Mari B, Guerin S, Farahi F, Breittmayer J, Belhacene N, Peyron J, Rossi B and Auberger $\mathrm{P}(1996)$ Thrombin and trypsin-induced $\mathrm{Ca}(2+)$ mobilization in human $T$ cell lines through interaction with different protease-activated receptors. FASEB J. 10: 309-316

66. Campbell K, Cooper S, Dessing M, Yates S and Buder A (1998) Interaction of p59fyn kinase with the dynein light chain, Tctex-1, and colocalization during cytokinesis. J. Immunol. 161: 1728-1737

67. Finke J, Zea A, Stanley J, Longo D, Mizoguchi H, Tubbs R, WiltroutR, O'SheaJ, Kudoh S, Klein E, et al. (1993) Loss of T cell receptor ' chain and p56lck in T-cell infiltrating human renal cell carcinoma. Cancer Res. 53: 5613-5616

68. Gastman B, Johnson D, Whiteside T and Rabinowich H (1999) Caspasemediated degradation of T-cell receptor $\zeta$ chain. Cancer Res. 59: 1422-1427

69. Kersh E, Shaw Eand Allen P (1998) Fidelity of T cell activation through multistep T cell receptor $\zeta$ chain phosphorylation. Science 281: $572-575$

70. Penna D, Müller S, Martinon F, Demotz S, Iwashima M and Valitutti S (1999) Degradation of ZAP-70 following antigenic stimulation in human $T$ lymphocytes: role of calpain proteolytic activity. J. Immunol. 163: 50-56

71. Sarin A, Nakajima H and HenkartP (1995) A protease-dependent TCR-induced death pathway in mature lymphocytes. J. Immunol. 154: 5806-5812

72. Squier M and Cohen J (1997) Calpain, an upstream regulator of thymocyte apoptosis. J. Immunol. 158: 3690-3697

73. Datta R, KojimaH, Yoshida Kand Kufe D (1997)Caspase-3-mediated cleavage of protein kinase $C$ theta in induction of apoptosis. J. Biol. Chem. 272: 2031720320

74. McGinnis K, Whitton M, Gnegy M and Wang K (1998) Calcium/calmodulindependent protein kinase IV is cleaved by caspase-3 and calpain in SH-SY5Y human neuroblastoma cells undergoing apoptosis. J. Biol. Chem. 273: 1999320000

75. Boise L, Gottschallk A, Quintans J and Thompson C (1995) Bcl-2 and Bcl-2related proteins in apoptosis regulation. Curr. Top. Microbiol. Immunol. 200: 107-121

76. Yang $E$ and Korsmeyer S (1996) Molecular thanatopsis: a discourse on the BCL2 family and cell death. Blood 88: 386-401

77. Kyriakis J and Avruch J (1996) Protein kinase cascades activated by stress and inflammatory cytokines. Bioessays 18: $567-577$

78. Boise L, Gonzalez-Garcia M, Postema C, Ding L, Lindsten T, Turka L, Mao X, Nunez G and Thompson C (1993) Bcl-x, a bcl-2-related gene that functions as a dominant regulator of apoptotic cell death. Cell 74: 597-608

79. Fang W, Rivard J, Mueller D and Behrens T (1994) Cloning and molecular characterization of mouse bcl-x in B and T lymphocytes. J. Immunol. 153: $4388-4398$

80. Shaham S and Horvitz H (1996) An alternatively spliced C. elegans ced-4 RNA encodes a novel cell death inhibitor. Cell 86: 201-208

81. Screaton G, Xu X-N, Olsen A, Cowper A, Tan R, McMichael A and Bell J (1997) LARD: A new lymphoid-specific death domain containing receptor regulated by alternative pre-mRNA splicing. Proc. Natl. Acad. Sci. USA 94: 4615-4619

82. Wang L, Miura M, Bergeron L, Zhu H and Yuan J (1994) Ich-1, an ICE/ced-3related gene, encodes both positive and negative regulators of programmed cell death. Cell 78: $739-750$

83. Jiang Z and Wu J (1999) Alternative splicing and apoptosis. Proc. Soc. Exp. Biol. Med. 220: 64-72

84. Rutjes SA, Utz PJ, Broekhuis C, van der Heijden A, van Venrooij WJ and Pruijn GJM (1999) The La (SS-B) autoantigen, a key protein in RNA biogenesis, is dephosphorylated and cleaved early during apoptosis. Cell Death Differ. 6: 976-986

85. Casciola-Rosen LA, MillerDK, Anhalt GJ and Rosen A (1994) Specific cleavage of the $70 \mathrm{kDa}$ protein component of the $\mathrm{U} 1$ small nuclear riboprotein is a characteristic biochemical feature of apoptotic cell death. J. Biol. Chem. 269: 30757-30760 
86. Utz PJ, Hottelet M, van Venrooij WJ and Anderson P (1998) The $72 \mathrm{kDa}$ component of the signal recognition particle is cleaved during apoptosis. J. Biol. Chem. 273: 35299-35361

87. Utz PJ, Hottelet M, Schur P and Anderson P (1997) Proteins phosphorylated during stress-induced apoptosis are common targets for autoantibody production in patients with systemic lupus erythematosus. J. Exp. Med. 185: $843-854$

88. Utz PJ, Hottelet M, van Venrooij WJ and Anderson P (1998) Association of phosphorylated SR proteins and the U1-small nuclear ribonuclear protein autoantigen complex accompanies apoptotic cell death. J. Exp. Med. 187: $547-560$

89. Fu XD (1995) The superfamily of arginine/serine-rich splicing factors. RNA. 1: $663-680$

90. Colwill K, Pawson T, Andrews B, Prasad J, Manley J, Bell J and Duncan P (1996) The clk/sty protein kinase phosphorylates SR splicing factors and regulates their intranuclear distribution. EMBO J. 15: 265-275

91. Colwill K, Feng L, Yeakley J, Gish G, Caceres J, Pawson T and Fu XD (1996) SRPK1 and Clk/Sty protein kinases show distinct substrate specificities for serine/arginine-rich splicing factors. J. Biol. Chem. 271: 24569-24575

92. Gui J, Lane W and Fu XD (1994) A serine kinase regulates intracellular localization of splicing factors in the cell cycle. Nature 369: 678-682

93. Gui J, Tronchere H, Chandler S and Fu XD (1994) Purification and characterization of a serine kinase specific for the serine- and arginine-rich pre-mRNA splicing factors. Proc. Natl. Acad. Sci. USA 91: 10824-10828

94. Kuroyanagi N, Onogi H, Wakabayashi T and Hagiwara M (1998) Novel SRprotein-specific kinase, SRPK2, disassembles nuclear speckles. Biochem. Biophys. Res. Comm. 242: 357-364

95. Wang H, Lin W, Dyck J, Yeakley J, Songyang Z, Cantley L and Fu XD (1998) SRPK2: A differentially expressed SR protein-specific kinase involved in mediating the interaction and localization of pre-mRNA splicing factors in mammalian cells. J. Cell. Biol. 140: 737-750

96. Rossi F, LabourierE, Forne T, Divita G, DerancourtJ, Riou J, AntoineE, Cathala G, Brunel C and Tazi J (1996) Specific phosphorylation of SR proteins by mammalian DNA topoisomerase I. Nature 381: 80-82

97. Casiano CA, Martin SJ, Green DR and Tan EM (1996) Selective cleavage of nuclear autoantigens during CD95 (Fas/Apo-1)-mediated T cell apoptosis. J. Exp. Med. 184: $765-770$

98. Samejima K, Svingen P, Basi G, Kottke T, Mesner P, Stewart L, Durrieu F, Poirier G, Alnemri E, Champoux J, Kaufmann S and Earnshaw W (1999) Caspase-mediated cleavage of DNA topoisomerase I at unconventional sites during apoptosis. J. Biol. Chem. 274: 4335-4340

99. Jiang Z, Zhang W, Rao Y and Wu J (1998) Regulation of Ich-1 pre-mRNA alternative splicing and apoptosis by mammalian splicing factors. Proc. Natl. Acad. Sci. USA 95: $9155-9160$

100. Nishizuka $Y$ (1995) Protein kinase $C$ and lipid signaling for sustained cellular responses. FASEB J. 9: 484-496

101. Tanabe F, Cui $S$ and Ito M (1998) Ceramide promotes calpain-mediated proteolysis of protein kinase $\mathrm{C}$ beta in murine polymorphonuclear leukocytes. Biochem. Biophys. Res. Commun. 242: 129-133

102. Santoro M, Annand R, Robertson M, Peng Y, Brady M, Mankovich J, Hackett M, Ghayur T, Walter G, Wong W and Giegel D (1998) Regulation of protein phosphatase $2 \mathrm{~A}$ activity by caspase-3 during apoptosis. J. Biol. Chem. 273: $13119-13128$

103. Tschopp J, Irmler M and Thome M (1998) Inhibition of fas death signals by FLIPs. Curr. Opin. Immunol. 10: 552-558

104. Jackson S, MacDonald J, Lees-Miller S and Tjian R (1990) GC box binding induces phosphorylation of Sp1 by a DNA-dependent protein kinase. Cell 63: $155-165$

105. Lees-Miller S, SakaguchiK, Ullrich S, Appella E and Anderson C (1992) Human DNA-activated protein kinase phosphorylates serines 15 and 37 in the aminoterminal transactivation domain of human p53. Mol. Cell Biol. 12: 5041-5049

106. Shieh S, Ikeda M, Taya $Y$ and Prives C (1997) DNA damage-induced phosphorylation of $\mathrm{p} 53$ alleviates inhibition by MDM2. Cell $91: 325-334$

107. Yan M, Dai T, Deak J, Kyriakis J, Zon L, Woodgett J and Templeton D (1994) Activation of stress-activated protein kinase by MEKK1 phosphorylation of its activator SEK1. Nature 371: 798-800

108. Chan W, Yu J and Yang S (1998) Heat-shock stress induces cleavage and activation of PAK2 in apoptotic cells. J. Protein Chem. 17: 485-494

109. Frost $J$ (1997) Cross-cascade activation of ERKs and ternary complex factors by Rho family proteins. EMBO J. 21: 6426-6438
110. Tuazon P, Spanos W, Gump E, Monnig C and Traugh J (1997) Determinants for substrate phosphorylation by p21-activated protein kinase (gamma-PAK). Biochemistry 36: 16059-16064

111. Ramos E, Wysolmerski R and Masaracchia R (1997) Myosin phosphorylation by human cdc42-dependent S6H4/kinase/yPAK from placenta and lymphoid cells. Receptors and Signal Trans. 7: 99-110

112. Enslen $H$, Tokumitsu $H$ and Soderling $T$ (1995) Phosphorylation of CREB by CaM-kinase IV activated by CaM-kinase IV kinase. Biochem. Biophys. Res. Commun. 207: 1038-1043

113. Sun $P$, Lou Land Maurer R (1996) Regulation of activating transcription factor-1 and the CAMP response element-binding protein by $\mathrm{Ca} 2+/$ calmodulindependent protein kinases type I, II, and IV. J. Biol. Chem. 271: 3066-3073

114. Miranti C, Ginty D, Huang G, Chatila T and Greenberg M (1995) Calcium activates serum response factor-dependent transcription by a Ras- and Elk-1independent mechanism that involves a $\mathrm{Ca} 2+/$ calmodulin-dependent kinase. Mol. Cell. Biol. 15: 3672-3684

115. Ho N, Gullberg M and Chatila T (1996) Activation protein 1-dependent transcriptional activation of interleukin 2 gene by $\mathrm{Ca} 2+/$ calmodulin kinase type IV/Gr. J. Exp. Med. 184: 101-112

116. Alevizopoulos A, Dusserre Y, Ruegg U and Mermod N (1997) Regulation of the transforming growth factor beta-responsive transcription factor CTF-1 by calcineurin and calcium/calmodulin-dependent protein kinase IV. J. Biol. Chem. 272: 23597-23605

117. Alevizopoulos A and Mermod N (1997) Transforming growth factor-beta: the breaking open of a black box. Bioessays 19: 581-591

118. Sahyoun N, McDonald O, Farrell F and Lapetina E (1991) Phosphorylation of a Ras-related GTP-binding protein, Rap-1b, by a neuronal $\mathrm{Ca} 2+$ /calmodulindependent protein kinase, CaM kinase Gr. Proc. Natl. Acad. Sci. USA 88: 2643-2647

119. Madhavan $\mathrm{R}$ and Jarrett $\mathrm{H}$ (1999) Phosphorylation of dystrophin and alphasyntrophin by $\mathrm{Ca}(2+)$-calmodulin dependent protein kinase II. Biochim. Biophys. Acta. 1434: 260-274

120. Feinmesser R, Wicks S, Taverner C and Chantry A (1999) Ca2+/calmodulindependent kinase II phosphorylates the epidermal growth factor receptor on multiple sites in the cytoplasmic tail and serine 744 within the kinase domain to regulate signal generation. J. Biol. Chem. 274: 16168-16173

121. Banin S, Gout I and Brickell P (1999) Interaction between Wiskott-Aldrich Syndrome protein (WASP) and the Fyn protein-tyrosine kinase. Mol. Biol. Rep. 26: $173-177$

122. Kanda H, Mimura T, Hamasaki K, Yamamoto K, Yazaki Y, Hirai H and Nojima Y (1999) Fyn and Lck tyrosine kinases regulate tyrosine phosphorylation of p105CasL, a member of the p130Cas docking protein family, in T-cell receptormediated signalling. Immunology 97: 56-61

123. Hunter S, Burton E, Wu S and Anderson S (1999) Fyn associates with Cbl and phosphorylates tyrosine 731 in $\mathrm{Cbl}$, a binding site for phosphatidylinositol 3 kinase. J. Biol. Chem. 274: 2097-2106

124. Ron D, Napolitano E, Voronova A, Vasquez N, Roberts D, Calio B, Caothien R, Pettiford S, Wellik S, Mandac J and Kauvar L (1999) Direct interaction in T-cells between thetaPKC and the tyrosine kinase p59fyn. J. Biol. Chem. 274: 1900319010

125. Yeakley J, Tronchere H, Olesen J, Dyck J, Wang H and Fu XD (1999) Phosphorylation regulates in vivo interaction and molecular targeting of serine/ arginine-rich pre-mRNA splicing factors. J. Cell. Biol. 145: 447-455

126. Mou T, Kraas J, Fung E and Swope S (1998) Identification of a dynein molecular motor component in Torpedo electroplax; binding and phosphorylation of Tctex-1 by Fyn. FEBS Letters 435: 275-281

127. RicciJ, Maulon L, Luciano F, Guerin S, Livolsi A, Mari B, BreittmayerJ, Peyron J and Auberger $P$ (1999) Cleavage and relocation of the tyrosine kinase P59FYN during Fas-mediated apoptosis in T lymphocytes. Oncogene 18: 3963-3969

128. Deckert M, Tartare-Deckert S, Couture C, Mustelin T and Altman A (1996) Functional and physical interactions of Syk family kinases with the Vav protooncogene product. Immunity 5: 591-604

129. Wardenburg J, Fu C, Jackman J, Flotow H, Wilkinson S, Williams D, Johnson R, Kong G, Chan A and Findell P (1996) Phosphorylation of SLP-76 by the ZAP-70 protein-tyrosine kinase is required for T-cell receptor function. J. Biol. Chem. 271: $19641-19644$

130. Zhang W, Sloan-Lancaster J, Kitchen J, Trible R and Samelson L (1998) LAT: the ZAP-70 tyrosine kinase substrate that links $T$ cell receptor to cellular activation. Cell 92: 83-92 
131. Schlapfer D, Hauck C and Sieg D (1999) Signaling through focal adhesion kinase. Prog. Biophys. Mol. Biol. 71: 435-478

132. Burridge Kand Chrznowsky-Wodnicka M (1996) Focal adhesions, contractility, and signaling. Ann. Rev. Cell. Biol. 12: 463-519

133. Macdonald $S$, Crews $C$, Wu L, Driller J, Clark R, Erikson R and McCormick $F$ (1993) Reconstitution of the Raf-1-MEK-ERK signal transduction pathway in vitro. Mol. Cell. Biol. 13: 6615-6620

134. Huang W, Alessandrini A, Crews $C$ and Erikson R (1993) Raf- 1 forms a stable complex with Mek1 and activates Mek1 by serine phosphorylation. Proc. Natl. Acad. Sci. USA 90: 10947-10951

135. Datta S, Dudek H, Tao X, Masters S, Fu H, Gotoh Y and Greenberg M (1997) Ak phosphorylation of BAD couples survival signals to the cell-intrinsic death machinery. Cell 91: 231-241

136. Dekker $L$ and Parker $P$ (1997) Regulated binding of the protein kinase $C$ substrate GAP-43 to the V0/C2 region of protein kinase C-delta. J. Biol. Chem. 272: $12747-12753$

137 Ghayur T, Hugunin M, Talanian R, Ratnofsky S, Quinlan C, Emoto Y, Pandey P, Datta R, Huang Y, Kharbanda S, Allen H, Kamen R, Wong W and Kufe D (1996) Proteolytic activation of protein kinase $\mathrm{C}$ delta by an ICE/CED2-like protease induces characteristics of apoptosis. J. Exp. Med. 184: 2399-2404

138. Municio M, Lozano J, Sanchez P, Moscat J and Diaz-Meco M (1995) Identification of heterogenous ribonucleoprotein $\mathrm{A} 1$ as a novel substrate for protein kinase C zeta. J. Biol. Chem. 270: 15884-15891

139. Frutos S, Moscat J and Diaz-Meco M (1999) Cleavage of zetaPKC but not lambda/iotaPKC by caspase-3 during UV-induced apoptosis. J. Biol. Chem. 274: $10765-10770$

140. Häussermann S, Kittstein W, Rincke G, Johannes F-J, Marks F and Gschwend $M$ (1999) Proteolytic cleavage of protein kinase $C \mu$ upon induction of apoptosis in U937 cells. FEBS Letters 462: 442-446

141. Cryns V, Byun Y, Rana A, Mellor H, Lustig K, Ghanem L, Parker P, Kirschner M and Yuan J (1997) Specific proteolysis of the kinase protein kinase C-related kinase 2 by caspase-3 during apoptosis. Identification by a novel, small pool expression cloning strategy. J. Biol. Chem. 272: 29449-29453
142. Mukai H, Toshimori M, Shibata H, Kitagawa M, Shimakawa M, Miyahara M, Sunakawa $\mathrm{H}$ and Ono Y (1996) PKN associates and phosphorylates the headrod domain of neurofilament protein. J. Biol. Chem. 271: 9816-9822

143. Mukai H, Toshimori M, Shibata H, Takanag H, Kitagawa M, Miyahara M, Shimakawa M and Ono Y (1997) Interaction of PKN with alpha-actinin. J. Biol. Chem. 272: $4740-4746$

144. Matsuzawa K, Kosako H, Inagaki N, Shibata H, Mukai H, Ono Y, Amano M, Kaibuchi K, Matsuura Y, Azuma I and Inagaki M (1997) Domain-specific phosphorylation of vimentin and glial fibrillary acidic protein by PKN. Biochem. Biophys. Res. Commun. 234: 621-625

145. Takahashi M, Mukai H, Toshimori M, Miyamoto M and Ono Y (1998) Proteolytic activation of PKN by caspase-3 or related protease during apoptosis. Proc. Natl. Acad. Sci. USA 95: 11566-11571

146. McGowan C and Russell P (1993) Human Wee1 kinase inhibits cell division by phosphorylating p34cdc2 exclusively on Tyr15. EMBO J. 12: 75-85

147. Lupher M, Rao N, Eck M and Band H (1999) The Cbl protooncoprotein: a negative regulator of immune receptor signal transduction. Immunol Today 20: $375-382$

148. Meisner H, Conway B, Hartley D and Czech M (1995) Interactions of Cbl with Grb2 and phosphatidylinositol $3^{\prime}$-kinase in activated Jurkat cells. Mol. Cell. Biol. 15: $3571-3578$

149. Elly C, Witte S, Zhang Z, Rosnet O, Lipkowitz S, Altman A and Liu Y (1999) Tyrosine phosphorylation and complex formation of $\mathrm{Cbl}-\mathrm{b}$ upon $\mathrm{T}$ cell receptor stimulation. Oncogene 18: 1147-1156

150. Zhang Z, Elly C, Qiu L, Altman A and Liu Y (1999) A direct interaction between the adaptor protein $\mathrm{Cbl}-\mathrm{b}$ and the kinase ZAP-70 induces a positive signal in T cells. Curr. Biol. 9: 203-206 